\title{
Dongeng: Media Pemahaman Multibudaya Bagi Generasi Penduduk Global
}

\author{
Yuli Wahyuni ${ }^{1}$, Christy Tisnawijaya ${ }^{2}$, Haryati ${ }^{3}$, \\ Lisa Suhayati $^{4}$, Ratu Prayuana ${ }^{5}$
}

\author{
Universitas Pamulang \\ Korespondensi: dosen02313@unpam.ac.id ${ }^{1}$, dosen01357@unpam.ac.id², \\ dosen00511@unpam.ac.id ${ }^{3}$,dosen00604@unpam.ac.id ${ }^{4}$,dosen01443@unpam.ac.id ${ }^{5}$
}

\begin{abstract}
Community Service is part of the Three Pillars of Higher Education which is obligatory for lecturers to conduct each semester. The existence of acts of bullying, a lack of tolerance and supportive feeling among teenagers are the main backgrounds of this community service activity. This article discusses a program of community service aimed specifically to enhance multiculturalism awareness. This program was delivered through videos of storytelling using stick puppets by several lecturers and students of the English Department of Universitas Pamulang and designed for tutors and children in Jampang English Village Bogor. The method used to analyze the data is the descriptive analysis that illustrates the effects of using storytelling on children's cognitive skills. After watching a video with a fairy tale using a hand puppet, it was found that there was an increase in the skills of the participants in terms of cooperation, listening, language acquisition, creativity, imagination, and multicultural awareness. The knowledge obtained is expected to provide new enthusiasm in escalating motivation and conveying materials related to multiculturalism awareness as an attempt to build a peaceful society.
\end{abstract}

Keywords: JEV, multiculturalism, storytelling, video

\begin{abstract}
Abstrak
Pengabdian kepada Masyarakat adalah salah satu unsur dalam Tri Dharma Perguruan Tinggi yang wajib dilaksanakan oleh setiap dosen pada tiap semesternya. Adanya tindakan perundungan, kurangnya rasa tenggang rasa dan perasaan saling mendukung di antara para remaja menjadi latar belakang utama dari kegiatan pengabdian kepada msyarakat ini. Artikel ini membahas kegiatan pengabdian masyarakat yang bertujuan meningkatkan kesadaran multikulturalisme di kalangan reamaja. Kegiatan pengabdian ini dilakukan oleh beberapa dosen dan mahasiswa Program Studi Sastra Inggris Universitas Pamulang melalui pembuatan video dongeng dengan menggunakan stick puppets sebagai properti. hal ini ditujukan kepada tutor dan para peserta didik di Jampang English Village (JEV) Bogor. Melalui metode deskriptif analitis, data memperlihatkan beberapa pengaruh mendongeng terhadap keterampilan kognitif anak. Setelah menyaksikan video yang bersisi dongeng dengan menggunakan hand puppet, ditemukan adanya peningkatan keterampilan peserta dalam hal kerjasama, mendengarkan, pemerolehan bahasa, kreatifitas, imajinasi, dan kesadaran multikultural. Pengetahuan yang diperoleh melalui kegiatan pengabdian ini diharapkan dapat menciptakan semangat baru dalam meningkatkan motivasi dan menciptakan materi-materi terkait kesadaran multikultural, sebagai upaya mewujudkan situasi damai dalam kehidupan bermasyarakat.
\end{abstract}

Kata kunci: JEV, mendongeng, multikulturalisme, video 


\section{A. Pendahuluan}

Ketidakmampuan bersosialisasi dan kurangnya rasa empati menyebabkan terjadinya bullying (perundungan). Menurut KBBI online, perundungan berasal dari kata rundung berarti "mengganggu, mengusik terus-menerus, menyusahkan" (2019). Dalam salah satu artikel CNN Indonesia dikemukakan beberapa hal yang dapat dikategorikan sebagai perundungan yaitu: "mengejek, memanggil dengan bukan nama sebenarnya, berkelahi, dan mengucilkan" (CNNIndonesia.com/ Jumat, 11-10-2019). Menurut hasil survei Program for International Student Assessment (PISA) tahun 2018, sebanyak 41\% siswa di Indonesia adalah korban perundungan (Permana, 2019). Lebih lanjut lagi, data Komisi Perlindungan Anak Indonesia (KPAI) mengemukakan bahwa pengaduan tertinggi sampai April tahun 2019 adalah kasus bullying atau kekerasan psikis di berbagai tingkat sekolah (Rahayu, 2019).

Pada beberapa kasus, keberagaman identitas budaya atau kondisi multibudaya di Indonesia adalah pemicu ketidakharmonisan interaksi sosial. Di jenjang pendidikan formal, kurangnya toleransi dalam menyikapi perbedaan merupakan salah satu alasan siswa untuk melakukan perundungan (bullying) yang tak jarang pula berkelanjutan menjadi tawuran antarpelajar (Sari, 2014). Mengatasi hal ini, pendidikan karakter perlu ditingkatkan bukan hanya melalui jenjang pendidikan formal tetapi juga melalui kegiatan pembelajaran informal. Pendidikan karakter toleransi, cinta damai, dan peduli sosial adalah tiga hal utama yang diperlukan untuk menciptakan keharmonisan peradaban bangsa multikultural atau multibudaya (Budhiman, 2017). Di era ini, pendidikan dan pengajaran tidak hanya terpaku terhadap hal yang kaitannya dengan pengembanag intelektual saja. Hal lain yang tak kalah pentingnya adalah pendidikan mengenai sikap perilaku dan karakter. Lickona (1991) menjelaskan bahwa pendidikan karakter merupakan suatu usaha yang disengaja untuk dapat membantu seseorang dia dapat memahami, memperhatikan dan melakukan nilai-nilai etika yang inti. Hal ini tidak bisa dipupuk hanya dari rumah saja, tetapi juga di lembaga oendidikan baik formal maupun informal dan tentuny dari masyarakat sekitar yang tidak bisa diabaikan peranan pentingnya terhadap pembentuka karakter anak di tengah majemuknya budaya (multiculturalism) yang ada.

Multikultural, menurut KBBI daring (2016), bermakna "bersifat keberagaman budaya". Dalam hal ini, multikultural mengacu pada kondisi komunitas di suatu tempat. Sementara itu, multikulturalisme artinya mengakui dan menghargai berbagai variabel identitas, tanpa memaksa minoritas untuk menyesuaikan identitasnya mengikuti identitas mayoritas (Stanford Encyclopedia of Philosophy, 2016). Hal ini sejalan dengan makna kata toleransi yaitu "sikap atau sifat menghargai, membiarkan, membolehkan pendirian seseorang baik itu pendapat, pandangan, kepercayaan, kebiasaan, dsb yang berbeda atau yang bertentangan dengan pendiriannya" (PDSPK, 2017, p. 2). Pendidikan karakter toleransi diperlukan untuk mencegah perpecahan dalam kondisi majemuk Bangsa Indonesia yang terdiri dari banyak suku bangsa, adat istiadat, bahasa daerah, dan kepercayaan. 
Keragaman budaya, terutama di Indonesia, telah berjalan selama ratusan tahun sejak datangnya para pedagang dari India, Timur Tengah, Eropa, dll ke Indonesia ratusan tahun silam. Maka dari itu, keragaman dalah suatun kewajaran dalam msayarakat yang harus disikapi dan dihayati dengan penuh toleransi dan tenggang rasa. "Multikulturalisme adalah landasan budaya yang terkait dengan pencapaian civility (keadaban) yang amat penting bagi terwujudnya demokrasi yang berkeadaban dan keadaban yang demokrasi (Azra, 2004). Ini berarti, jika keragaman dapat disikapi dengan baik, maka solidaritas nasional dalam terbentuk dan ini sangat baik bagi perkembangan bangsa kita ke depannya.

Salah satu unit kegiatan masyarakat di daerah Bogor yang menjalankan program penguatan pendidikan karakter menerapkan konsep belajar sambil bermain dengan menggunakan Bahasa Inggris yaitu Jampang English Village (JEV), berlokasi di Kampung Wisata Jampang, Jalan Raya Parung, Bogor-Jawa Barat, disponsori oleh Dompet Dhuafa didirikan pada tahun 2015. Jampang English Village atau Kampung Inggris Jampang adalah rangkaian program pemberdayaan terpadu di daerah Bogor. JEV memiliki program utama "English Green Zone" terdiri dari enam kelas Bahasa Inggris interaktif yang terbuka untuk semua usia, dengan pembagian tiga kelas di Jampang Pulo (RW 03) dan tiga kelas di Jampang Poncol (RW 6). Kelas-kelas Bahasa Inggris ini dibuka dengan latar belakang pemahaman akan pentingnya keterampilan Bahasa Inggris bagi penunjang karir. Setiap tahun, JEV mengadakan English Festival yang mengundang sekolah-sekolah di Jabodetabek untuk berpartisipasi dalam tiga perlombaan yaitu: spelling bee, storytelling, dan scrabble.

Program Studi Sastra Inggris bekerja sama dengan Lembaga Penelitian dan Pengabdian kepada Masyarakat Universitas Pamulang melihat adanya kebutuhan masyarakat mitra, JEV, untuk meningkatkan keterampilan Bahasa Inggris khususnya keterampilan storytelling. Secara etimologi, kata storytelling berasal dari bahasa Inggris yang tersusun dari dua kata, yaitu story dan telling. Story artinya cerita dan telling artinya menceritakan. Jadi padanan kata tersebut menghasilkan sebuah pengertian baru yaitu menceritakan sebuah cerita (Echols \& Shadily, 2006). Storytelling adalah kegiatan aktif, bercerita secara terstruktur dan utuh kepada pendengarnya. Hal ini sebagaimana diutarakan oleh Ellis \& Brewster "telling a story to people who are willing to listen" (2014, p. 25). Menurut Harlynne (1997) ada tiga tahapan dalam storytelling, yaitu persiapan sebelum acara storytelling dimulai, saat proses storytelling berlangsung, hingga kegiatan storytelling selesai.

Storytelling, sebagai wujud sastra lisan adalah media yang baik untuk penyampaian pendidikan karakter di tengah maraknya kasus perundungan Storytelling atau mendongeng dalam Bahasa Inggris dapat meningkatkan minat baca (Niswah, 2013) dan kemampuan berbahasa anak (Ariani, 2019). Storytelling merupakan salah satu kegiatan kreatif dengan beberapa manfaat baik bagi pencerita maupun bagi pendengarnya (Dispusip Pekanbaru, 2019). Kami, tim PkM yang terdiri dari lima dosen dan dua belas mahasiswa memilih tema "Dongeng: Media Pemahaman Multibudaya bagi Generasi Penduduk Global" dalam rangka membantu pengembangan program JEV English Festival. 


\section{B. Pelaksanaan dan Metode}

Kegiatan Pengabdian kepada Masyarakat di Program Studi Sastra Inggris pada semester genap tahun ajaran 2019/2020 ini dilakukan dengan metode yang berbeda. Biasanya, seluruh kelompok Pengabdian kepada Masyarakat datang langsung ke lokasi mitra untuk melakukan kegiatan. Akibat merebaknya wabah Covid-19 di seluruh dunia termasuk Indonesia, maka hampir seluruh pemerintah daerah menerapkan aturan PSBB (Pembatasan Sosial Berskala Besar) atas arahan pemerintah pusat. Dampaknya, hampir seluruh sektor termasuk pendidikan tidak dapat melakukan kegiatan secara tatap muka, termasuk para mitra Pengabdian kepada Masyarakat di Prodi Sastra Inggris. Oleh karena itu, kegiatan Pengabdian kepada Masyarakat dilakukan melalui pembuatan video pembelajaran sesuai tema yang telah disusun oleh masing-masing kelompok Pengabdian kepada Masyarakat yang telah dirumuskan dalam proposal sejak awal semester genap tahun 2019/2020. Video pembelajaran yang telah dipersiapkan oleh tim PkM dan diberikan kepada koordinator JEV. Pihak JEV lalu mendistribusikan video pembelajaran tersebut kepada peserta didik. Berikut 3 video pembelajaran yang disajikan oleh tim PkM:

1) Video pembahasan tentang storytelling dan multiculturalism Video ini menyajikan definisi, proses, dan manfaat storytelling dan pemahaman multikulturalisme yang ditujukan kepada tenaga pengajar JEV. Isi video disesuaikan dengan penjabaran pada bagian pendahuluan.

2) Video tutorial pembuatan stick puppets untuk bekal kreatifitas siswa Video ini berisi tutorial pembuatan stick puppets yang disesuaikan dengan cerita yang dongeng yang akan dijadikan storytelling.

3) Video Storytelling

Video ini menampilkan storytelling yang bertujuan untuk memberikan pemahaman multikulturalisme. Adapun storytelling disajikan dengan menggunakan media stick puppets dan menggunakan Bahasa Inggris.

\section{Hasil dan Pembahasan}

Pengabdian kepada Masyarakat yang diselenggarakan melalui media pembelajaran berupa video ini memiliki beberapa manfaat bagi para peserta didik yang dijabarkan ke dalam penjelasan berikut ini:

\section{Melatih Kerjasama}

Video pembelajaran yang dibuat untuk peserta didik JEV berisi beberapa cerita yang sangat menarik yang disajikan dengan menggunakan stick puppets yang mewakili masing-masing karakter di dalam cerita. Setelah menonton video pembelajaran, peserta PkM merasa memiliki keinginan untuk melakukan hal yang sama, yakni menyajikan satu cerita dengan menggunakan stick puppets seperti yang mereka lihat di dalam video. Keinginan itu diwujudkan oleh para peserta didik dengan berkolaborasi mulai dari membuat stick puppets, merangkai cerita bersama, hingga menampilkannya. Hal ini menunjukan bahwa video 
pembelajaran ini berhasil mendorong dan memotivasi para peserta didik untuk dapat bekerjasama dengan teman sebaya mereka.

\section{Peningkatan Kemampuan Mendengar dan Pemerolehan Bahasa Anak}

Dengan ditampilkannnya video pembelajaran yang menyajikan storytelling dengan karakter beraneka ragam hewan berwarna warni yang seolaholah bisa bicara, para peserta didik begitu antusias menonton dan mendengarkan isi cerita yang disajikan. Media yang menarik seperti ini terbukti dapat meningkatkan antusiasme para peserta didik untuk dapat dengan seksama mendengarkan isi cerita dengan seksama. Selain peningkatan keterampilan dalam mendengarkan, proses tersebut mengarahkan anak didik dalam proses pemerolehan kosa kata baru dalam bahasa Inggris. Video pembelajaran menyajikan kosa kata yang mudah dipahami oleh perserta didik dan mereka dapat menirukan kosa kata yang dipelajari dengan baik dan tepat.

\section{Peningkatan Daya Imajinasi dan Kreatifitas}

Video pembelajaran juga berisi tata cara atau prosedur pembuatan stick puppets. Jika melihat video storytelling, kita dapat menyaksikan bahwa stick puppets yang disajikan sagat menarik lengkap dengan latar belakang. Hal ini memunculkan kreatifitas dan imajinasi para peserta didik. Mereka berpikir bagaimana cara membuat stick puppets seperti yang ada di dalam video. Di dalam video tutorial pembuatan stick puppets, ditampilkan bagaimana kardus-kardus bekas diolah dan dibentuk sedemikian rupa sehingga menjadi stick puppets yang sangat menarik. Ini membuat para peserta didik tertarik untuk membuat hal yang serupa. Setelah mendapatkan inspirasi dari tayangan video pembelajaran yang disaksikan, para peserta didik mempraktekkan untuk membuat stick puppets sendiri. Mereka menonton video tata cara pembuatan, mulai dari menggambar pola, mewarnai, hingga memasang stick puppets yang sudah selesai dibuat pada sebilah tongkat kecil (lihat gambar 1). Hal ini membuktikan bahwa tayangan yang ada di dalam video pembelajaran dapat merangsang daya imajinasi dan kreatifitas para peserta didik.

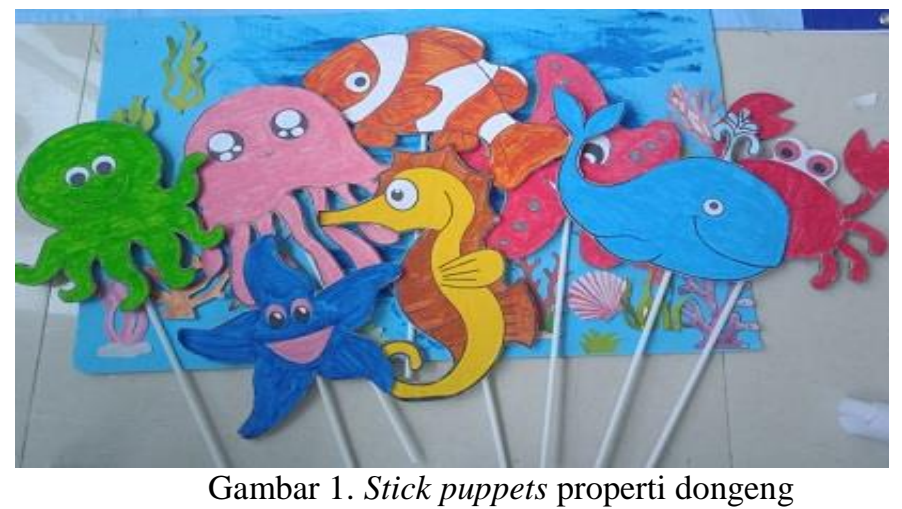

\section{Pemahaman tentang Budaya Multikultural}

Berdasarkan jawaban peserta didik atas pertanyaan dari para tutor, maka diperoleh hasil bahwa banyak dari para peserta didik awalnya belum memahami 
apa itu kemajemukan budaya. Mereka hanya mengetahui perihal perbedaan suku dan agama yang mereka pelajari melaui guru-guru mereka di sekolah. Setelah menonton video pembelajaran berikut penjelasannya, mereka tahu bahwa perbedaan budaya tidak hanya persoalan suku dan agama saja, tetapi juga perbedaan mengenai nilai hidup, pendapat, karakter, gender, sosial ekonomi dan lain sebagainya. Pemahaman mengenai budaya multikultural memang harus dimiliki oleh oleh para anak karena ini akan membantu mereka dalam beradaptasi dengan lingkungan sekitarnya. Pemahaman ini akan membantu mereka untuk dapat memperlakukan teman-teman dan orang lain sama dan tidak membedakan tanpa memandang latar belakang budaya, jenis kelamin, karakter, maupun latar belakang sosial ekonomi. Dengan demikian anak-anak ini pada nantinya dapat hidup berdampingan dalam lingkungan sekitar bahkan dunia yang memang terdapat banyak sekali perbedaan budaya sehingga tercipta kehidupan yang harmonis dan saling berdampingan satu sama lain.

\section{Penutup}

\section{Simpulan}

Penggunaan video untuk menyampaikan cerita dalam bentuk storytelling mengantarkan empat pengaruh positif terhadap peserta $\mathrm{PkM}$ dan perkembangan kognitif yang lainnya. (1) Storytelling melatih anak untuk berkerjasama dengan rekan mereka yang lain atau berkolaborasi menceritakan cerita yang mereka telah pahami sebelumnya. (2) Kemampuan mendengarkan anak dapat berkembang dengan signifikan karena peserta PkM dilatih untuk mendengarkan cerita atau dongeng; proses inilah yang membantu mereka untuk memahami cerita melaui mendegar. Lebih jauh lagi, peserta didik memperoleh beberapa kosa kata baru yang dapat mereka serap saat menyaksikan video pembelajaran tersebut, dan mereka dapat menerapkan kosa kata baru tersebut dalam kegiatan mereka (3) Kegiatan ini pun melatih peserta $\mathrm{PkM}$ untuk menggali dan meningkatkan daya kreatifitas dan imajinasi mereka dalam menghasilkan sebuah cerita yang baru yang berhubungan dengan budaya di daerah mereka dan berkreasi dengan menggunakan media pendukung untuk cerita tersebut. (4) Adanya kesadaran dalam diri peserta mengenai multikulturalisme. Kegiatan ini memberikan gambaran mengenai perbedaan budaya yang mereka miliki dengan budaya yang ditampilkan dalam cerita tersebut. Mereka mengetahui perbedaan bahasa, cara berkomunikasi di dalam cerita, dan latar belakang dari cerita yang mereka simak. Dengan ini kesadaran para peserta didik akan pentingnya sikap tenggang rasa, saling menghormati dan saling mendukung satu sama lain dapat diimplementasikan dalam kehidupan mereka sehari-hari sebagai bagian dari masyarakat yang majemuk.

\section{Saran}

Penulis menyarankan kepada orangtua dan tutor untuk terus memupuk rasa tenggang rasa, toleransi dan saling mendukung para peserta didik terhadap orang lain terutama teman sebaya mereka. Mengajarkan kemajemukan budaya (multiculurasim) melalui story telling adalah salah satu upaya yang bisa sama- 
sama kita lakukan. Selain itu, penulis berharap kepada pihak JEV Bogor untuk lebih sering melakukan pembinaan dan penyuluhan kepada para perserta untuk meningkatkan kreatifitas mereka dengan menggunakan virtual learning di saat pandemi seperti ini.

\section{Ucapan Terima Kasih}

Ucapan terima kasih kami sampaikan kepada Yayasan Sasmita Jaya, LPPM Universitas Pamulang, Program Studi Sastra Inggris Fakultas Sastra, dan tentu saja Jampang English Village sebagai mitra kegiatan Pengabdian kepada Masyarakat atas dukungan terhadap kegiatan PkM ini.

\section{DAFTAR PUSTAKA}

Ariani, L. (2019). Storytelling sebagai metode dalam mengembangkan kemampuan berbahasa pada anak prasekolah. Diakses pada 5 Maret 2020 dari http://fppsi.um.ac.id/wp-content/uploads/2019/07/5-STORYTELLINGSEBAGAI-METODE-DALAM-MENGEMBANGKAN-KEMAMPUANBERBAHASA-PADA-ANAK-PRASEKOLAH-36-44.pdf

Azra. A (2006). 'Pancasila dan Identitas Nasional Indonesia: Perspektif Multikulturalisme”. Dalam Restorasi Pancasila: Mendamaikan Politik identitas dan Modernitas. Bogor. Brighten Press. Jakarta: Rineka Cipta

Budhiman, A. (2017). Gerakan penguatan pendidikan karakter. Diakses pada 6 Maret 2020 dari http://repositori.kemdikbud.go.id/10096/1/Paparan_PPK__Dr_Arie_Budhiman__M_Si.pdf

CNN Indonesia (2019). Bullying jadi pintu masuk ide bunuh diri pada remaja. Diakses pada 6 Maret 2020 dari https://www.cnnindonesia.com/gayahidup/20191009115236-255-438016/bullying-jadi-pintu-masuk-ide-bunuhdiri-pada-remaja

Dispusip Pekanbaru (2019). Storytelling dan manfaat dari storytelling. Diakses pada 5 Maret 2020 dari https://dispusip.pekanbaru.go.id/storytelling-danmanfaat-dari-storytelling/

Echols, J. M., \& Shadily, H. (2006). Kamus Inggris-Indonesia: an EnglishIndonesian Dictionary. Jakarta: Gramedia.

Ellis, G., \& Brewster, J. (2014). Tell it again! the storytelling handbook for primary English language teachers. March 5, 2020. https://www.teachingenglish.org.uk/article/tell-it-again-storytellinghandbook-primary-english-language-teachers

Harlynne, G. (1997). Storytelling professionally: The nuts and bolts of a working performer. Diakses pada 10 Juni 2020 dari https://books.google.co.id/books?id=018z0zAoovoC\&pg=PR3\&lpg=PR3\& $\mathrm{dq}=$ Geisler + Harlynne. $+(1997) \&$ source $=$ bl\&ots=kNG5lpHXk\&sig=ACfU3U1cdvYXjJzrRip60OUzJuJrM7wEOQ\&hl=jv\&sa=X\&ved=2a 
hUKEwiymePwuMTqAhVp63MBHYDfAOMQ6AEwAHoECAoQAQ\#v= onepage \&q=Geisler\%20Harlynne.\%20(1997)\&f=false

Multikultural. (2016). KBBI Daring. Diakses pada 13 Juli 2020 dari https://kbbi.kemdikbud.go.id/entri/multikultural

Niswah, S. (2013). Pengaruh metode storytelling terhadap pengembangan minat baca dan bahasa anak kelompok $b$ di tk tunas bangsa pati tahun ajaran 2012/2013. Skirpsi. Surakarta: Fakultas Keguruan dan Ilmu Pendidikan Universitas Muhammadiyah Surakarta. Diakses pada 5 Maret 2020 dari http://eprints.ums.ac.id/26492/11/NASKAH_PUBLIKASI.pdf

Permana, R.H. (2019). Pisa 2018: 41\% Siswa indonesia korban bullying, 17\% dilanda kesepian. Diakses pada 6 Maret 2020 dari https://news.detik.com/berita/d-4809711/pisa-2018-41-siswa-indonesiakorban-bullying-17-dilanda-kesepian?single $=1$

Pusat Data dan Statistik Pendidikan dan Kebudayaan (PDSPK) Kementerian Pendidikan dan Kebudayaan Republik Indonesia. (2017). Analisis faktorfaktor yang memengaruhi sikap tolerasi di Indonesia. Diakses pada 5 Maret 2020 dari http://publikasi.data.kemdikbud.go.id/uploadDir/isi_FE52CE11862A-42C3-9527-DB09E874C6C4_.pdf

Rahayu, L.S. (2019). Kpai: Angka kekerasan pada anak januari-april 2019 masih tinggi. Diakses pada 6 Maret 2020 dari https://news.detik.com/berita/d4532984/kpai-angka-kekerasan-pada-anak-januari-april-2019-masih-tinggi

Rundung (2019). Kamus besar bahasa indonesia (kbbi) online. Diakses pada 6 Maret 2020 dari https://kbbi.web.id/rundung

Sari, Y.M. (2014). Pembinaan toleransi dan peduli sosial dalam upaya memantapkan watak kewarganegaraan (civic disposition) siswa. Jurnal Pendidikan Ilmu Sosial, Vol. 23, No. 1. Diakses pada 13 Juli 2020 dari https://ejournal.upi.edu/index.php/jpis/article/view/2059

Standford Encyclopedia of Philosophy. (2016). Multiculturalism. Diakses pada 13 Juli 2020 dari https://plato.stanford.edu/entries/multiculturalism/

Zonamadina (n.d.). Jampang English Village. Diakses pada 6 Maret 2020 dari https://zonamadina.com/program/jev/ 